\title{
Seyhan havzasında Palmer indeksleri ile kuraklık analizi
}

\author{
${ }^{* 1}$ Mehmet Dikici ${ }^{1}$ Cengiz İpek ve ${ }^{1}$ İsmail Topçu \\ ${ }^{1}$ Faculty of Engineering, Department of Civil Engineering, Alanya Alaaddin Keykubat University, Alanya \\ Turkey
}

\begin{abstract}
Özet
Kuraklık, geniș alanlarda ve belirli bir zaman aralığında su kullanımının önemli derecede azalmasını tarif eden doğal bir olaydır. Dünyanın değişik bölgelerinde meydana gelen kuraklık, ekonomik faaliyetlere, insan yaşamına ve ekosistem ile alakalı çeşitli faktörlere etki eder. Küresel hidrolojik çevrimin karmaşık olması nedeni ile kuraklığın kökenini belirlemek gerçek anlamda mümkün olamamaktadır. Ancak küresel ısınmanın yanında şehirleşmenin etkisi yadsınamaz bir gerçektir. Bu çalışmada, Seyhan havzasında ölçülmüş olan aylık ortalama yağış, sıcaklık ve su tutma kapasiteleri kullanılarak Palmer kuraklık şiddeti indisi (PDSI) metoduna göre kuraklığın saptanması hedeflenmiştir. Seyhan Havzası kuraklık analizi çalışması kapsamında kullanılacak meteorolojik, hidrolojik ve hidrojeolojik veriler için veri boşluk analizi yapılarak veri varlığı değerlendirilmiş, en uzun ve uygun ortak periyot olarak meteorolojik verilerin analizinde 1970-2016, hidrolojik ve hidrojeolojik verilerin analizinde 1970-2015 yılları esasa alınmıştır. Seyhan havzasında yavaş ilerleyen bir kuraklık olduğu kanaatine varılmıştır.
\end{abstract}

Anahtar Sözcükler: Kuraklık, Seyhan Havzası, Palmer kuraklık indisi

\section{Giriş}

Günümüzde iklim değişikliğinin olumsuz olarak etkilediği su kaynaklarının planlaması, geliştirilmesi ve yönetimi çalışmaları kapsamında, kuraklığın beklenen etkilerinin hafifletilmesi konusu oldukça önem kazanmıştır. Artan kuraklık riskinin yönetilmesi ve bu riske uyum sağlanması; ancak bütüncül yaklaşımları benimseyen sürdürülebilir ve etkili kuraklık risk yönetimi stratejilerinin geliştirilmesi ile olur. Kuraklık yönetimi afet yönetiminin bir parçasıdır. Kuraklık Risk Yönetimi; korunma, zarar azaltma ve hazırlıklı olma amaçlı faaliyetler ve önlemler yoluyla kuraklık tehlikesinin olumsuz sonuçlarını ve potansiyel afet etkilerini engelleme ve azaltma kavramı ve çalışmasıdır.

Kuraklığı üç ana başlıkta tarif edebiliriz;

1) Meteorolojik kuraklık; genellikle göreceli olarak daha kısa zaman zarflarında (1-6 ay) gerçekleşen yağış verisinin kullanıldığı indikatörler ve indeksler ile analiz edilmektedir.

2) Hidrolojik kuraklık; yüzey ve yer altı suyu verileri kullanıldığı ve göreceli olarak daha uzun zaman zarflarında (6-12 ay) gerçekleşen yağış verilerinin kullanıldığı indikatörler ve indeksler sayesinde tespit edilmektedir.

3) Tarımsal kuraklık; bitki için gerekli olan toprak neminin yeterli değerin altında olması ile özdeşleştirilmesi sebebiyle genellikle uzaktan algılama yöntemleri ile elde edilebilen bitki örtüsü ve toprak nemi verilerinden hesaplanan indeksler sayesinde ve meteorolojik veriler ile bitkisel üretim verileri yoluyla tespit edilmektedir.

Farklı zaman dilimlerinde etkili olabilen kuraklık olaylarının incelenmesi ve izlenmesi amacıyla çeşitli yaklaşım ve yöntemler geliştirilmiştir. Geliştirilen yöntemlerde yer alan indikatörler, indeksler ve eşik değerler kuraklık koşullarının başlangıcını saptamak, kuraklık 
olaylarını ölçmek, izlemek ve kuraklık afetinin büyüklüğünün belirlenmesi açısından önem taşımaktadır.

Yağış, sıcaklık ve toprağın su tutma kapasitesi verilerine göre geliştirilen Palmer indeksi bu çalışma kapsamında kullanılmış ve 4 farklı indeks için Seyhan havzasının kuraklık analizi yapılmıştır.

\section{Malzeme ve Yöntem}

\section{1. Çalışma Alanı}

Toplam yağış alanı $20.731 \mathrm{~km}^{2}$ olan Seyhan Havzası'nın yıllık ortalama yağış yüksekliği 624 $\mathrm{mm}$; yıllık ortalama akışı ise $211,07 \mathrm{~m}^{3} / \mathrm{s}^{-1}$ dir. Y1llık ortalama verimi $10,18 \mathrm{~L} / \mathrm{s}^{-1} \mathrm{~km}^{3}$ olan havzadaki akışın yağışa oranı 0,51 iken, iştirak oranı $\% 3,62$ 'dir [1].

\subsection{Seyhan Havzası Kuraklık Analizi Kapsamında Kullanılan Veriler}

Seyhan Havzası kuraklık analizi çalışması kapsamında kullanılacak meteorolojik, hidrolojik ve hidrojeolojik veriler için veri boşluk analizi yapılarak veri varlığı değerlendirilmiş, en uzun ve uygun ortak periyot olarak meteorolojik verilerin analizinde 1970-2016, hidrolojik ve hidrojeolojik verilerin analizinde 1970-2015 yılları esas alınmıştır.

$\mathrm{Bu}$ periyotlar dikkate alınarak çalışmada kullanılan tüm parametrelerin eksik yılları PRISM (Parameter-elevation Relationships on Independent Slopes Model-Parametre Yükseklik İlişkisi Bağımsız Eğim Modeli) metodu ile enterpolasyon yapılarak tamamlanmış ve kesintisiz zaman serileri elde edilerek kuraklık analizi çalışması gerçekleştirilmiştir.

Seyhan Havzası kuraklık analizi çalışması kapsamında havza sınırları içinde kalan 15 adet MGI'den elde edilen verilerden faydalanılmıştır. Ayrıca havza sınırlarına yakın olan komşu havzalardaki 9 adet MGİ verisi de alansal analizlere olan etkileri göz önünde bulundurularak kuraklık analizlerinde kullanılmıştır.

\subsection{Palmer Kuraklık Indeksleri}

\subsubsection{Palmer Kuraklık Şiddeti İndeksi (PDSI)}

Sıcaklık ve yağış verilerinin su dengesi bilgisiyle birleştirilerek elde edilen Palmer Kuraklık Şiddeti İndeksi (PDSI) [2] ilk olarak Amerika Birleşik Devletleri'nin mahsul üretilen bölgelerindeki kuraklığın tespit edilmesi amacıyla geliştirilmiştir.

PDSI, aylık yağış, sıcaklık ve toprağın su tutma kapasitesi verileri kullanılarak hesaplanmaktadır. Palmer yönteminin hesaplama süreci, bahsedilen verilerin kullanılmasıyla su dengesine göredir. Su dengesinin temel parametreleri olan evapotranspirasyon, toprağa geçen su, yüzey akışı ve yüzeyden nem kaybı belirlenebilmektedir ancak sulama gibi insan etkileri dikkate alınmamaktadır. Genellikle aylık olarak hesaplanan PDSI, pozitif ise nemli, negatif ise kurak periyodu ifade eder. Palmer kuraklık şiddeti indisi aşağıdaki şekilde hesaplanır:

$$
X_{i}=X_{i-1}+\frac{Z_{i}}{3}-0,103 * X_{i-1}
$$

Burada $X_{i}$, i'nci ay için hesaplanan PDSI değeridir. Palmer'ın yaklaşımına göre, kurak ve nemli koşulların sınıflandırılması amacıyla yukarıda verilmiş olan Palmer genel eşitliği, kurak ya da nemli devrelerin başlangıcını ve bitimini belirlemek için üç indise ayrılmıştır:

- $\mathrm{X}_{1}=$ Nemli bir dönemin başlangıcını sağlayan şiddet indisi, 
- $\quad \mathrm{X}_{2}=$ Kurak bir dönemin başlangıcını sağlayan şiddet indisi,

- $\mathrm{X}_{3}=$ Herhangi bir kurak ya da nemli dönemin başladığını belirleyen indis,

$\mathrm{X} 1$ değerleri daima pozitif; X2 değerleri ise daima negatiftir, $\mathrm{X} 1 \geq 1,0$ olduğunda nemli devrenin etkili olmaya başladığı; X2 $\leq 1,0$ olduğunda ise kuraklık olayının etkili olmaya başladığ 1 kabul edilir. X3, daha önce etkili olmuş ve sürmekte olan kuraklık olayının ya da nemli devrenin şiddetini belirlediği için, en geniş anlamıyla kuraklık açısından daha çok bilgi içerir ve bu yüzden de daha önemlidir [3].

PDSI için literatürde yaygın olarak kullanılan kuraklık şiddetleri ve eşik değerleri [2] Tablo 1 ile verilmiştir.

Tablo 1. Palmer Kuraklık Şiddeti İndeksi (PDSI) Kuraklık Sınıflandırması ve Eşik Değerleri

\begin{tabular}{|c|c|}
\hline Eşik Değerler & Kuraklık/Nemlilik Sınıfı \\
\hline 4,00 ve üzeri & Aşırı Nemli \\
\hline $3,00-3,99$ & Çok Nemli \\
\hline $2,00-2,99$ & Orta Nemli \\
\hline $1,00-1,99$ & Az Nemli \\
\hline $0,50-0,99$ & Nemli Devre Başlangıcı \\
\hline $\mathbf{0 , 4 9}-\mathbf{- 0 , 4 9}$ & Normal Civarı \\
\hline$-0,50--0,99$ & Kuru Devre Başlangıcı \\
\hline$-1,00--1,99$ & Hafif Kurak \\
\hline$-2,00--2,99$ & Orta Kurak \\
\hline$-3,00--3,99$ & Şiddetli Kurak \\
\hline$-4,00$ ve altı & Aşırı Kurak \\
\hline
\end{tabular}

\subsubsection{Kendinden Kalibreli Palmer Kuraklık Şiddeti İndeksi (scPDSI)}

PDSI 'nin zayıf noktası PDSI değerlerinin mekânsal karşılaştırmasının zorluğudur, bu nedenle kendi kendini kalibre eden bir Palmer Kuraklık Şiddet İndeksi (sc-PDSI) metodolojisi geliştirilmiştir. Sc-PDSI 'in farkı indeks hesaplamasındaki ampirik sabitlerin dinamik olarak hesaplanan değerlerle değiştirilmesi ve indeksin davranışını otomatik olarak kalibre edebilmesidir [4].

scPDSI, PDSI içerisindeki tüm ampirik katsayılara açıklama getirerek katsayıların her bir istasyonun bulunduğu yerdeki mevcut özelliklere bağlı şekilde dinamik olarak hesaplandığı bir yöntem ortaya koyar. scPDSI'ın kendinden-kalibrasyon özelliği her bir istasyon için geliştirilir ve o yerin iklim rejimine göre değişir [5].

PDSI gibi scPDSI hesaplamaları için aylık sıcaklık, aylık yağış ve AWHC verileri gereklidir. Benzer şekilde scPDSI hesaplamalarında da sıcaklık ve yağış verilerinin eksiksiz zaman serisine sahip olması zorunludur, PDSI gibi scPDSI da yağışlı ve kuru ölçeklere sahiptir. Toprak nemi değerlerinin basitleştirilmesinden ötürü gerçekleşen kurak dönemlerin belirlenmesinde gösterdiği zaman farkı ve donmuş yağış ve zemin koşullarındaki performans eksikliği bakımından PDSI ile benzer sorunlara sahiptir. Yine benzer şekilde scPDSI meteorolojik, hidrolojik ve tarımsal kuraklık analizlerinde uygulanabilir bir indekstir.

Hesaplama yöntemi PDSI indeksinden çok farklı olan scPDSI sonuçlarında direkt olarak istasyon yeri ile ilintili olmasından dolayı aşırı olaylar nadirdir. Çünkü bu olaylar esas olarak 
bir katsayıyla alakalı değil istasyonun bilgisine bağlıdır. Bu yüzdendir ki scPDSI her bir alanda neler olduğunu yansıtarak farklı alanlar için daha doğru karşılaştırmalar yapılmasına olanak sağlar.

Kendinden Kalibreli Palmer Kuraklık İndeksi (scPDSI) için de Tablo 1 ile verilen PDSI kuraklık şiddetleri ve eşik değerleri kullanılmaktadır.

\subsubsection{Palmer Hidrolojik Kuraklık Indeksi (PHDI)}

Palmer Hidrolojik Kuraklık İndeksi (PHDI), orijinal PDSI'dan yola çıkarak elde edilmektedir yani PHDI, PDSI hesaplamalarının bir diğer çıktısıdır. PHDI, PDSI'nın su depolama, akım ve yer altı suyunu etkileyebilecek uzun dönemli kuraklığı göz önünde bulunduracak şekilde modifiye edilmesiyle elde edilmektedir. PHDI ile bir kuraklık olayının ne zaman biteceği, gerekli yağışa bağlı olarak alınan nemin kuraklığın bitmesi için gerekli olan neme oranını kullanarak hesaplanabilmektedir. PHDI için aylık sıcaklık ve yağış verisi gerekli olup sıcaklık ve yağış verilerinin eksiksiz zaman serisi olması zorunluluk göstermektedir.

PHDI'nin kullanımı su kaynaklarını uzun süreler boyunca etkileyebilecek kuraklıkları dikkate alması sebebiyle fayda sağlamaktadır. Yöntemin esas aldığı su dengesi yaklaşımı toplam su sisteminin değerlendirilmesine olanak sağlamaktadır. Bununla birlikte PHDI için söz konusu olan bazı dezavantajlar şunlardır:

(i) Kar erimesinden meydana gelen akışı hesaba katmaması [6],

(ii) Yağış ya da akım değişkenliğinin fazla olduğu bölgelerde yeterince etkili bir indeks olmamas1 [7],

(iii) Sulama sistemleri ya da uygulamaya ilişkin insan kaynaklı etkilerin hesaplamalarda göz önünde bulundurmamas1 [5],

(iv) Frekansların bölgeye ve zamana (aşırı kuraklığın nadir bir olay olmayabileceği yılın bazı ayları) göre değişmesi.

PHDI için literatürde yaygın olarak kullanılan kuraklık şiddetleri ve eşik değerleri PDSI için Tablo 1'de verilen değerlerle aynıdır.

\subsubsection{Kendinden Kalibreli Palmer Hidrolojik Kuraklık Indeksi (scPHDI)}

Kendinden Kalibreli Palmer Hidrolojik Kuraklık Şiddeti İndeksi scPHDI, PHDI içerisindeki tüm katsayılara açıklama getirerek katsayıların her bir istasyonun bulunduğu yerdeki mevcut özelliklerine bağlı olacak şekilde dinamik olarak hesaplandığı bir yöntem ortaya koyar. scPHDI de scPDSI gibi kendinden-kalibrasyon özelliği nedeniyle her bir istasyon için geliştirilir ve o yerin iklim rejimine göre değişiklik gösterir.

scPHDI'nin hesaplanması gereklidir çünkü PHDI hesaplanmasında kullanılan ampirik katsayılar özellikle ABD coğrafyası şartlarına göre kalibre edilmiştir. Bu sebepten ötürü yeniden kalibrasyonu, incelenen farklı bölgelerin şartlarının yansıtılması açısından oldukça önemlidir [8]. Kendinden Kalibreli Palmer Hidrolojik Kuraklık İndeksi (scPHDI) için literatürde yaygınlıkla kullanılan kuraklık şiddetleri ve eşik değerleri Tablo 1 ile verilmiştir.

Palmer kuraklık hesaplarında (PDSI, PHDI, scPDSI ve scPHDI) sıcaklık ve yağış parametrelerinin dişında toprak su tutma kapasitesine (Available Water Holding Capacity, AWHC) ihtiyaç duyulmaktadır. Bitkilerin topraktan alabildikleri su, yarayışlı su olarak ifade edilir ve Şekil 1'de görüldüğü üzere toprağın 1/3 atm'deki (pF 2.54) tarla kapasitesi (Field Capacity, FC) ile 15 atm'deki (pF 4.2) solma noktası (Wilting Point, WP) arasındaki gerilimle tutulan sudur. Yarayışılı su miktarı ise tarla kapasitesi ve solma noktası arasındaki fark ile elde edilmektedir:

$$
A W H C=F C-W P
$$




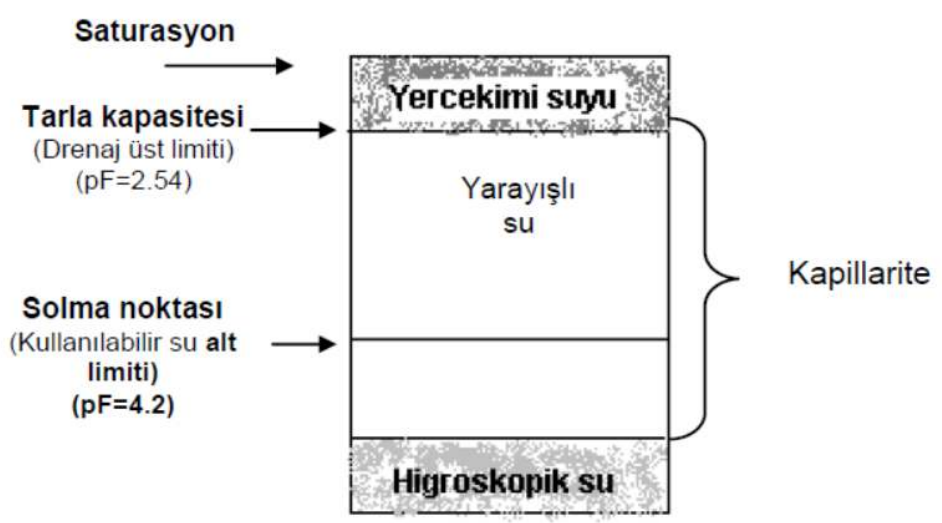

Şekil 1. Toprakta bulunan suyun grafiksel gösterimi (Allen, 1998)

Yarayışlı su miktarı toprak bünyesi, organik madde içeriği ve gözeneklerin durumuna göre değişiklik göstermektedir. Şekil 2'de de görüldüğü gibi yarayışlı su miktarı, en düşük değerlere kum ve/veya kumlu bünyeye sahip topraklarda ulaşırken; killi bünyeye sahip gruba ilerledikçe daha yüksek değerlere ulaşmaktadır.

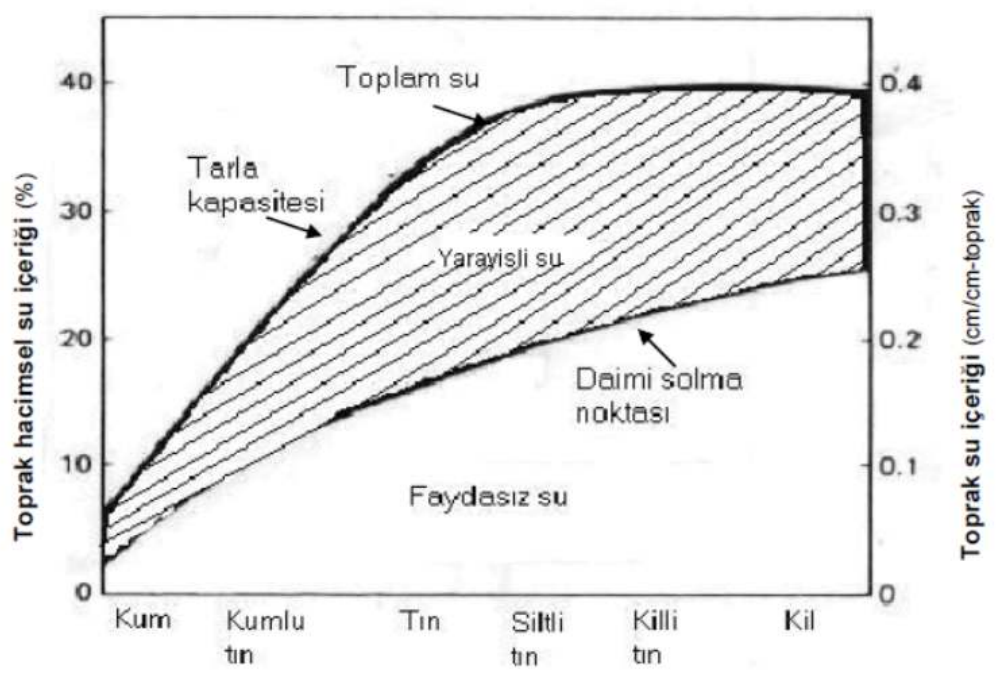

Şekil 2. Toprak bünyelerine göre yarayışlı ve yarayışlı olmayan su miktarının değişimi (Kramer, P. J., Boyer, J. S., 1995)

Yarayışlı su miktarı verisi ISRIC (International Soil Reference and Information Centre) tarafindan hazırlanan ve 2014 yılında yayınlanan $250 \mathrm{~m}$ (Soil Grids 250m) ve $1 \mathrm{~km}$ çözünürlükteki (Soil Grids $1 \mathrm{~km}$ ) toprak hücreleri (Soil Grids) sistemini kullanarak elde edilen mekânsal öngörülerin çıktıları olarak ifade edilen veri setinden sağlanabilmektedir. Bu veri seti istatistik analizleri kullanarak en güncel toprak parametreleri ile hazırlanmış küresel toprak bilgilerini içermektedir. Bu kapsamda çeşitli derinliklerde $(0,5,15,30,60,100$ ve $200 \mathrm{~cm})$ ve $(\mathrm{pF}=2.0, \mathrm{pF}=2.3, \mathrm{pF}=2.5)$ tarla kapasitelerinde üretilmiş topraktaki yarayışlı su miktarı hacimsel yüzdeler olarak verilmektedir. Proje kapsamında yarayışlı su miktarı; $100 \mathrm{~cm}$ derinlikteki toprak katmanındaki yarayışlı su değeri, toprak derinlikleri ile çarpılarak ve havzada belirli noktalarda araştırmalarla belirlenmiş yarayışı su miktarları ile doğrulanarak Palmer kuraklık analizleri için kullanıma hazır hale getirilmiştir.

Palmer kuraklık hesaplamaları için gerekli olan referans ortalama hava sıcaklığ değerleri meteoroloji istasyonlarına ait 1970-2016 yılları arasındaki 47 yıllık veriler kullanılarak 
bulunmuştur. $\mathrm{Bu}$ çalışmada Palmer kuraklık indeks verilerinin elde edilmesi sırasında ara aşama olarak elde edilen potansiyel buharlaşma ve terleme değerleri kullanım kolaylığı (sadece aylık ortalama sıcaklık değerlerine bağlı) açısından Thornthwaite yöntemi kullanılarak hesaplanmıştır. Penman-Monteith yöntemi kullanılarak daha doğru potansiyel buharlaşma ve terleme değerleri elde edilebilir. Fakat Palmer kuraklık indeks değerleri genel itibariyle kurak dönemlerde kullanılan potansiyel buharlaşma ve terleme değerlerine karşı hassas olmaması [9] sebebiyle bu çalışmada Thornthwaite yöntemi kullanılmıştır.

Hesaplama kodu ilgilenenlerin erişimine açık olan Palmer kuraklık indeksi uzun yıllar boyu operasyonel olarak kullanılan tek kuraklık indeksiydi. Günümüzde birçok kuraklık indeksi geliştirilmiş olmasına rağmen Palmer kuraklık analizleri tüm dünyada halen yaygın bir şekilde kullanılmaya devam etmektedir. Bu indekslerin avantajlarının en başında şüphesiz toprağa ait bilgilerin sıcaklık ve yağış ile beraber su bütçesinin elde edilmesi, akademik literatürde çok fazla uygulamasının bulunması ve hesaplama kodunun açık bulunması gelmektedir [5]. İndeksin kullanımını kısıtlayan etkenler [10] arasında hesaplama için tam zaman serisi verisi gerekliliği, hesaplamalardaki toprak neminin basitleştirilmesine bağlı kuraklık koşullarının belirlenmesinde zaman gecikmesine sebep olması, donmuş yağış ve zemin koşullarında iyi sonuç vermemesi ve sadece Birleşik Devletler için kalibre edilmiş olması sayılabilir [11].

\section{Bulgular}

\section{Palmer Kuraklık İndeksleri}

Palmer kuraklık indekslerine ait kuraklık şiddeti zaman serileri, Seyhan Havzası için hesaplanmıştır. Zamana göre değişen Palmer Kuraklık Şiddeti İndeksi (PDSI), Kendinden Kalibreli Palmer Kuraklık Şiddeti İndeksi (scPDSI), Palmer Hidrolojik Kuraklık İndeksi (PHDI) ve Kendinden Kalibreli Palmer Hidrolojik Kuraklık İndeksi (scPHDI) aylık değerleri öncelikle havzadaki istasyonlar için hesaplanmış, daha sonra bu değerler Seyhan Havzası'nın tümünü kapsayacak şekilde ağırlıklı ortalamalar ile alansallaştırılmıştır.

Palmer Kuraklık İndeksleri zaman serileri Şekil 3 ile gösterilmiştir. Serilerde mavi dönemler normal ve üzeri (nemli) dönemleri temsil etmekte olup kırmızı dönemler kurak dönemleri göstermektedir.

\section{Kuraklık Görülme Oranları}

Palmer Kuraklık İndekslerine ait kuraklık görülme oranları, Seyhan Havzası için istasyon bazlı hesaplanmış olup bu değerler aşağıda verilmiştir.

Seyhan Havzasındaki istasyonlar için sc-PDSI ve sc-PHDI indeksi sınıflandırmasına göre kuraklık görülme oranları sırasıyla Tablo 2 ve Tablo 3 üzerinde bu tablolara ilişkin grafikler Şekil 4 ve Şekil 5 ile verilmiştir. 

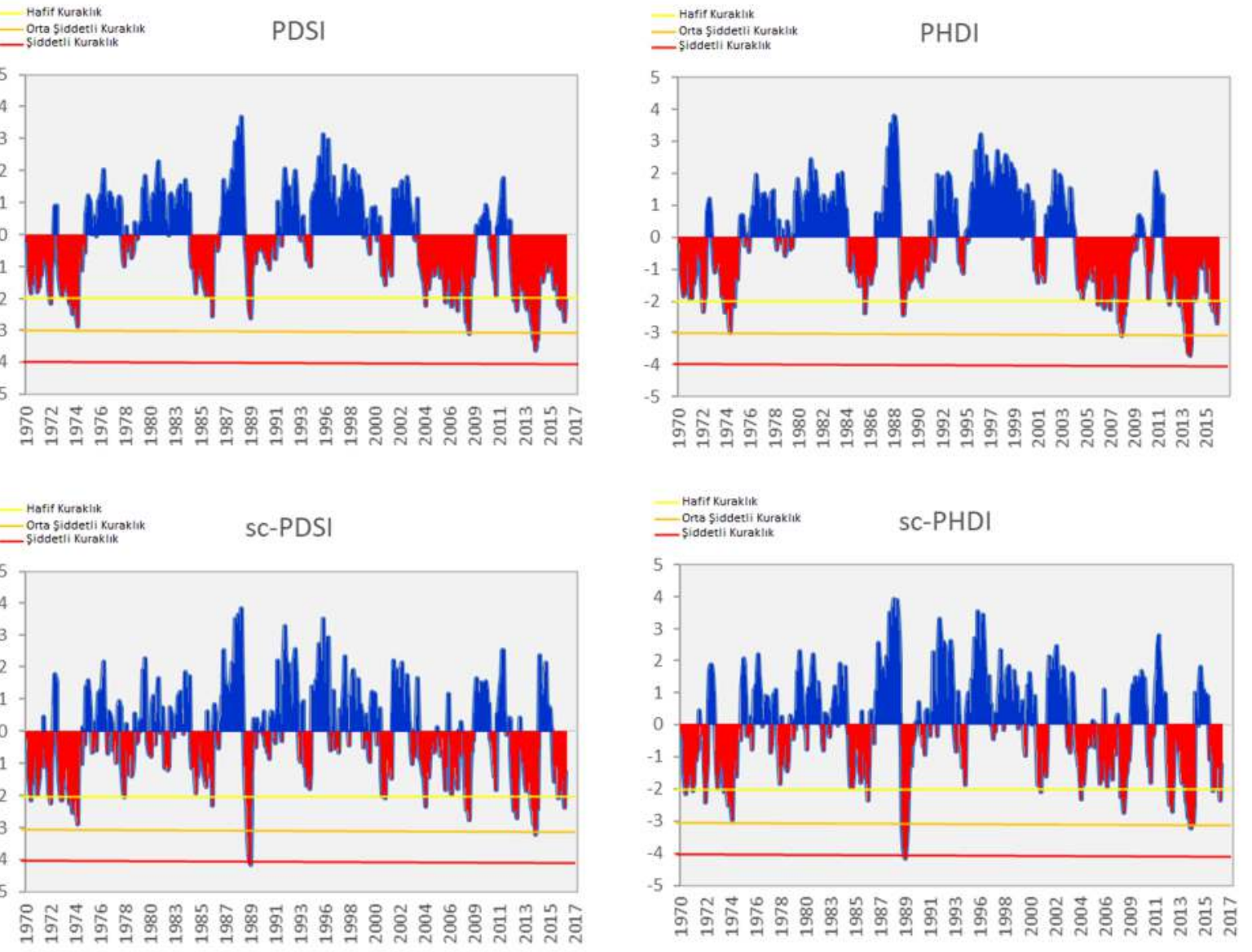

Şekil 3. Seyhan havzası PDSI, scPDSI, PHDI ve sc PHDI aylık zaman serileri

Tablo Hata! Belgede belirtilen stilde metne rastlanmadı.. Seyhan Havzası İçinde Kalan İstasyonlar sc-PDSI Kuraklık Oluşma Olasılıkları

\begin{tabular}{|l|c|c|c|c|}
\hline \multicolumn{1}{|c|}{ İstasyon Adı } & $\begin{array}{c}\text { Şiddetli } \\
\text { Kurak }\end{array}$ & $\begin{array}{c}\text { Orta } \\
\text { Şiddetli } \\
\text { Kurak }\end{array}$ & $\begin{array}{c}\text { Hafif } \\
\text { Kurak }\end{array}$ & $\begin{array}{c}\text { Normal } \\
\text { ve } \\
\text { Üzeri }\end{array}$ \\
\hline ADANA & $5,4 \%$ & $10,7 \%$ & $15,9 \%$ & $67,9 \%$ \\
\hline BAKIRDAĞI & $10,8 \%$ & $14,3 \%$ & $15,7 \%$ & $59,1 \%$ \\
\hline ÇATALAN & $4,7 \%$ & $13,6 \%$ & $16,3 \%$ & $65,4 \%$ \\
\hline ELBAŞI & $9,0 \%$ & $10,7 \%$ & $17,7 \%$ & $62,6 \%$ \\
\hline KARAİSALI & $4,9 \%$ & $12,5 \%$ & $17,8 \%$ & $64,9 \%$ \\
\hline KARATAŞ & $6,7 \%$ & $7,6 \%$ & $14,3 \%$ & $71,4 \%$ \\
\hline KAYNAR & $6,9 \%$ & $8,5 \%$ & $14,6 \%$ & $70,0 \%$ \\
\hline ÖRENŞEHİ & $8,3 \%$ & $11,9 \%$ & $21,7 \%$ & $58,0 \%$ \\
\hline PAZARÖREN & $7,4 \%$ & $16,5 \%$ & $19,6 \%$ & $56,5 \%$ \\
\hline PINARBAŞI & $13,6 \%$ & $18,8 \%$ & $19,7 \%$ & $47,8 \%$ \\
\hline POZANTI & $6,5 \%$ & $8,5 \%$ & $11,6 \%$ & $73,4 \%$ \\
\hline SARIZ & $8,9 \%$ & $13,0 \%$ & $17,0 \%$ & $61,1 \%$ \\
\hline TOKLAR & $13,8 \%$ & $15,4 \%$ & $16,3 \%$ & $54,5 \%$ \\
\hline TOMARZA & $8,5 \%$ & $10,9 \%$ & $23,2 \%$ & $57,4 \%$ \\
\hline
\end{tabular}




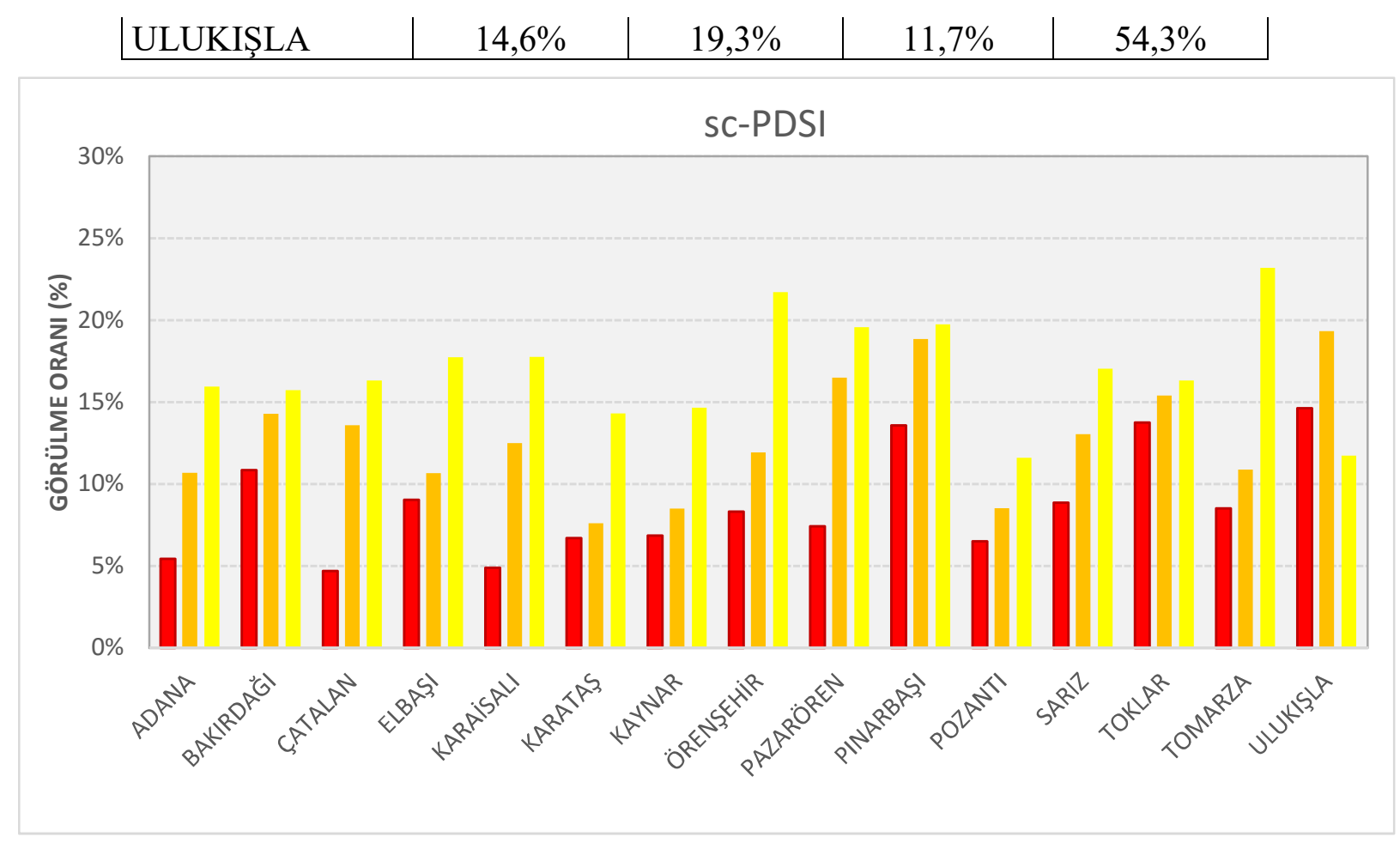

Şekil 4. Seyhan havzası içinde kalan istasyonlar sc-PDSI kuraklık oluşma olasılıkları

Yapılan değerlendirmeye göre hafif kuraklık görülme oranı en yüksek \%23,2 ile Tomarza'da, en düşük \%11,6 ile Pozantı'da, orta şiddetli kuraklık görülme oranı en yüksek \%19,3 ile Ulukışla'da, en düşük \% 7,6 ile Karataş'da, şiddetli kuraklık görülme oranı en yüksek \%16,6 ile Ulukışla'da, en düşük \%4,7 ile Çatalan'da görülmüştür.

Havza içerisinde kalan istasyonların ortalamalarına göre havzada şiddetli kuraklık görülme oranı $\% 8,7$, orta şiddetli kuraklık görülme oranı $\% 12,8$ ve hafif kuraklık görülme oranı ise $\% 16,9$ şeklinde hesaplanmıştır.

Tablo 3. Seyhan Havzası İçinde Kalan İstasyonlar sc-PHDI Kuraklık Oluşma Olasılıkları

\begin{tabular}{|l|c|c|c|c|}
\hline \multicolumn{1}{|c|}{ İstasyon Adı } & $\begin{array}{c}\text { Şiddetli } \\
\text { Kurak }\end{array}$ & $\begin{array}{c}\text { Orta } \\
\text { Şiddetli } \\
\text { Kurak }\end{array}$ & Hafif Kurak & $\begin{array}{c}\text { Normal } \\
\text { ve } \\
\text { Üzeri }\end{array}$ \\
\hline ADANA & $5,4 \%$ & $10,9 \%$ & $15,0 \%$ & $68,7 \%$ \\
\hline BAKIRDAĞI & $10,8 \%$ & $15,2 \%$ & $14,1 \%$ & $59,9 \%$ \\
\hline ÇATALAN & $4,7 \%$ & $13,8 \%$ & $17,0 \%$ & $64,5 \%$ \\
\hline ELBAŞI & $10,1 \%$ & $13,4 \%$ & $27,1 \%$ & $49,4 \%$ \\
\hline KARAİSALI & $4,9 \%$ & $13,4 \%$ & $13,9 \%$ & $67,8 \%$ \\
\hline KARATAȘ & $7,2 \%$ & $12,0 \%$ & $19,9 \%$ & $60,9 \%$ \\
\hline KAYNAR & $8,7 \%$ & $10,5 \%$ & $15,6 \%$ & $65,3 \%$ \\
\hline ÖRENŞEHİR & $9,9 \%$ & $14,8 \%$ & $27,3 \%$ & $47,9 \%$ \\
\hline PAZARÖREN & $8,3 \%$ & $21,2 \%$ & $23,9 \%$ & $46,6 \%$ \\
\hline PINARBAȘI & $15,4 \%$ & $22,5 \%$ & $24,1 \%$ & $38,0 \%$ \\
\hline POZANTI & $6,5 \%$ & $8,7 \%$ & $13,0 \%$ & $71,7 \%$ \\
\hline SARIZ & $9,4 \%$ & $15,8 \%$ & $21,0 \%$ & $53,8 \%$ \\
\hline TOKLAR & $14,3 \%$ & $18,1 \%$ & $21,6 \%$ & $46,0 \%$ \\
\hline TOMARZA & $8,7 \%$ & $12,7 \%$ & $26,1 \%$ & $52,5 \%$ \\
\hline
\end{tabular}




\begin{tabular}{|l|l|l|l|l|} 
ULUKIŞLA & $16,6 \%$ & $24,5 \%$ & $17,0 \%$ & $41,9 \%$ \\
\hline
\end{tabular}

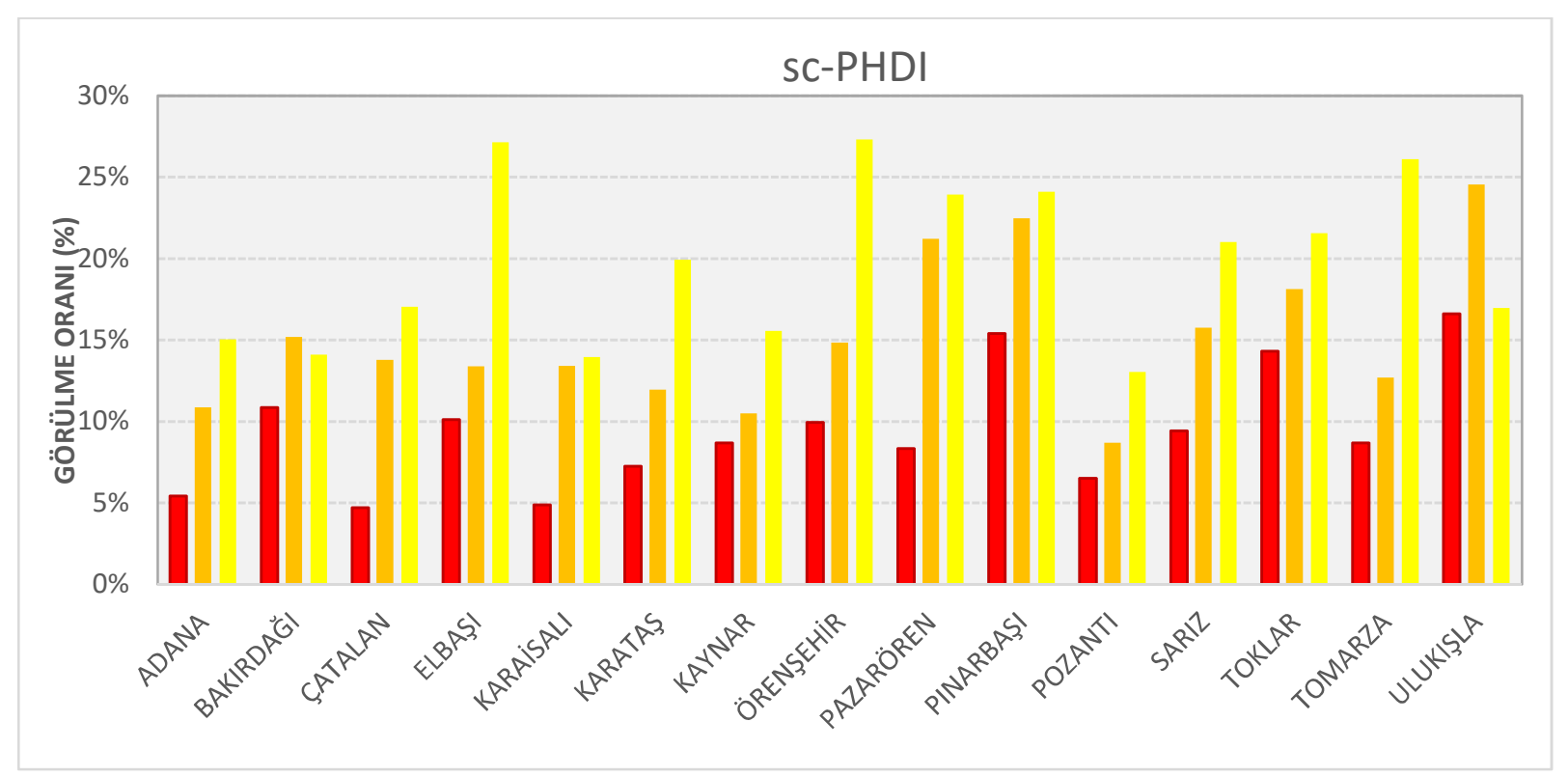

Şekil 5. Seyhan havzası içinde kalan istasyonlar sc-PHDI kuraklık oluşma olasılıkları

\section{Değerlendirme}

Yapılan değerlendirmeye göre hafif kuraklık görülme oranı en yüksek \% 27,3 ile Örenşehir'de, en düşük \%13,0 ile Pozantı'da, orta şiddetli kuraklık görülme oranı en yüksek \%22,5 ile Pınarbaşı'da, en düşük \%8,7 ile Pozantı'da, şiddetli kuraklık görülme oranı en yüksek \%15,4 ile Pınarbaşı' da, en düşük \%4,7 ile Çatalan'da görülmüştür.

Havza içerisinde kalan istasyonların ortalamalarına göre havzada şiddetli kuraklık görülme oranı $\% 9,4$, orta şiddetli kuraklık görülme oranı $\% 15,2$ ve hafif kuraklık görülme oranı ise \%19,8 şeklinde hesaplanmıştır.

\section{Sonuç}

Tüm indekslerin birlikte incelenmesi sonucunda; Seyhan Havzası için indekslerin ortak olarak kuraklığ işaret ettiği dönemler 1970-1974, 1984-1985, 1989, 2001, 2004-2009, 2013-2014 ve 2016 yılları olarak belirlenmiştir. Kuraklığın derecesi yıllara ve istasyonlara göre değişiklik göstermekle birlikte şiddetli kuraklığın en fazla görülme olasılığı \%16,6 ile Konya havzasına en yakın istasyon olan Ulukışla'da hesaplanmıştır. Havzanın genelinde yavaş seyreden bir kuraklıktan söz etmek mümkündür. Uzun vadeli kuraklık yönetim planları yapılmalıdır.

\section{Teşekkür}

Bu çalışmada, Orman ve Su İşleri Bakanlığı Su Yönetimi Genel Müdürlüğü’nün verileri paylaşmasından dolayı teşekkürü bir borç bilirim. 


\section{Kaynaklar}

[1] SYGM. www.suyonetimi.ormansu.gov.tr: Erişim 15.8.2018

[2] Palmer, W. Meteorological drought. U.S. Research Paper No. 45. Washington, DC: US Weather Bureau. 1965.

[3] Türkeş vd. Palmer Kuraklık İndisi'ne Göre İç Anadolu Bölgesi'nin Konya Bölümü’ndeki Kurak Dönemler ve Kuraklık Şiddeti. Coğrafi Bilimler Dergisi.2009

[4] Wells, N. Development of the self-calibrating Palmer Drought Severity Index. Lincoln: B.S. Honors thesis, University of Nebrask. 2002

[5] WMO. Handbook of Drought Indicators and Indices (M, Svoboda and B,A, Fuchs), Integrated Drought Management Programme (IDMP), Integrated Drought Management Tools and Guidelines Series 2. 2006

[6] Dai, A. Drought under global warming: a review. Wiley Interdisciplinary Reviews: Climate Change, 2(1), 45-65. 2011

[7] Şen, Z. Applied Drought Modeling, Prediction, and Mitigation (Chapter 2 - Basic Drought Indicators), Amsterdam: Elsevier. 2015

[8] Vicente-Serrano vd. Beguería, S., Lorenzo-Lacruz, J., Camarero, J. J., LópezMoreno, J. I., \& Azorin-Molina, C. . Performance of drought indices for ecological, agricultural, and hydrological applications. Earth Interactions, 16(10), 1-27. 2012

[9] Van der Schrier, G. The sensitivity of the PDSI to the Thornthwaite and PenmanMonteith parameterizations for potential evapotranspiration. Journal of Geophysical Research: Atmospheres, 116.D3. 2011

[10] Alley, W. The Palmer drought severity index: limitations and assumptions. Journal of Climate and Applied Meteorology, 23(7), 1100-1109. 1984

[11] Zargar vd., A. Sadiq, R., Naser, B., Khan, F. I. A review of drought indices. Environmental Reviews, 19, 333-349. 2011 